\title{
Recommendations on the Textbooks Creation as Information and Teaching Tools of Education Management
}

\author{
Ibragim D. Ibragimova ${ }^{a}$, Svetlana V. Dusenko ${ }^{\text {b }}$, Elmira R. Khairullinac, \\ Natalia V. Tikhonova ${ }^{c}$ and Olga G. Yevgrafova ${ }^{d}$
}

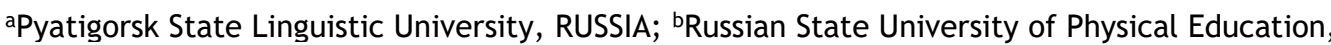
Sport, Youth and Tourism, RUSSIA; 'Kazan National Research Technological University, RUSSIA;

${ }^{\mathrm{d} K a z a n}$ (Volga region) Federal University, RUSSIA.

\begin{abstract}
The purpose of the paper is to develop recommendations for the textbooks' creation on social and humanitarian disciplines for university students. The study involves 300 teachers, 300 students, who express their requirements for the content and structure of textbooks, participate in the creation of the project of the textbook and its assessment. The main results of the study are to identify the textbook's functions (informational, transformational, systematizing, organizational and procedural, fixing and selfcontrolling, self-educational, scientific - research, integrating, coordinating, and social), to define current requirements for the structure and content of the textbook, criteria for assessing of its quality (relevance, content availability, optimality and versatility of structure, reliability). The significance of the results obtained is that the proposed content of the textbook integrates fundamental, subject and professional knowledge; the developed structure of the textbook is a systematic alternation of the texts, illustrations, apparatus to organize the mastering of knowledge (questions, assignments, examples, tasks, summarizing tables, conclusions).
\end{abstract}

KEYWORDS

Structure and content; textbook; functions; quality's assessment
ARTICLE HISTORY

Received 15 September 2015

Revised 10 November 2015

Accepted 22 February 2016

\section{Introduction}

The relevance of the study is conditioned by the new social order in the textbook and work with it (Kusainov \& Asylov, 2003). There are three main generations of educational books, which are different in functions, principles of construction and use. Books of the first generation can be only called books. They were intended, and, accordingly, created for readers to use for various purposes 
(Beilinson, 1986; Shaidullina et al., 2015 a; Sakhieva et al., 2015 a, b; Telegina et al., 2015). Learning tasks in the work with the book as a special one was not allocated and worked over. Nevertheless, authors very often turned to the reader in the books of this generation, seeking to be very attentive to them and in advance informed about the chapters' content to be read, gave advice, beyond the direct scientific content of the book. Unfortunately, all this almost gradually disappeared from the books and if it has a tendency to be revived, mostly in the scientific and popular literature, the role of which in the solution of educational problems deserves special attention and consideration.

The second generation of textbooks is those books which we use today. These textbooks are used at all levels of education. In the last decades they are tried to be improved, but these efforts do not lead to a radical solution of the problem. The reason for this is that principally they are textbooks of yesterday and do not solve the promising problems of today. The main feature of the second generation of textbooks is that they are intended, and, accordingly, are created with the direction to use them as tools in the hands of a teacher and nothing more, and as a result: the success of their functioning depends on the management actions of the teacher that, in turn, depend on the professional and personal characteristics. The role of textbooks, and hence its authors in these conditions, is hardly traced or deliberately distorted: on the one hand it is excessively magnified, and on the other hand it is unfairly belittled (Buga, 1987).

In recent years, more and more often there are books of another kind, which we refer to educational books of the third generation. Their birth is conditioned by the continuity of modern education, the shift in education from the traditionally established forms of classrooms, listening to bulky lectures on selfeducation and student's training with a text-book (Nazarova \& Gospodarik, 2005; Shaidullina et al., 2015 b; Kalimullin \& Vasyagina, 2015; Vlasova et al., 2016). Thus, the third generation of textbooks, in principle, intended for students with the expectation of its independent work and, therefore, they should carry out to some extent the function, which is still assigned to the teacher. Primarily, universities need in the creation of textbooks of the third generation. But these books are important and necessary for postgraduate professionals' self-education. Firstly, because it is necessary to prepare students to work independently with teaching book; secondly, it facilitates and improves the work of the teachers, they largely get rid of the stereotypical information functions, transferring these functions to the textbook's authors who realize them much better at the expense of their erudition; thirdly, a detailed exposition of educational material designed for independent work, facilitates the alignment of those students who for some reason lag behind the total flow, as well as the progress of those who succeed in teaching, has a desire to this promotion, which in turn, will facilitate the task to form positive motivation of the educational process (Batsyn \& Butyagina, 2005; Kamalova \& Zakirova, 2015; Lisitzina et al., 2015). Creating the textbooks of a new type requires appropriate training of authors, considerable effort and resources. Writing of a textbook is not a simple matter and one should carefully study the latest scientific research on textbooks' writing to be improved in the creation of original textbooks (Bespalko, 1986; Masalimova et al., 2014; Vlasova et al., 2015; Baklashova et al., 2015). The purpose of the paper is to develop recommendations for the textbooks' creation on social and humanitarian disciplines for university students. 


\section{Methodological Framework}

The guiding principle of research is the principle of integration which provides a combination of a base (common for all) component and a component of variability (the individually-differentiated) in the content of vocational education (Baklashova, 2014; Yashkova \& Kalimullin, 2015; Zakirova \& Koletvinova, 2014; Sakhieva et al., 2015 c; Kamasheva et al., 2016). At present, other goals and values are put before the education. They are not the knowledge, abilities and skills required for the performance of certain functions, but receptivity to new knowledge, ability to act in various environments. Knowledge is not important themselves, as the ultimate goal of education, but only as a means to achieve more important tasks. The world is presented not as a system of knowledge, but as the scope of activities, in which ones can and should be involved in order to carry out their plans. In the first place in the educational process personality and activities are nominated (cognition of the world in the process of structural transformation). The main purpose and value of vocational education is the maximum development of potential abilities, intelligence, flexibility and receptivity to innovation (Pugacheva et al., 2016; Sakhieva et al., 2015). During the research the following methods were used: theoretical (analysis, synthesis, generalization and systematization); sociological (observation, interviews, questionnaires, expert estimation).

\section{Results}

The main results of this study are: 1) the text-book's functions, 2) modern requirements to the content and structure of the textbook, 3) experimental verification of the effectiveness of modern requirements to the content and structure of the textbook.

\section{Textbook's functions}

It is found that teaching books are presented by the following types: 1) the material construction - these are book publications (textbooks, manuals, etc.), paper publications (tasks' forms, exam cards, etc.), posters; 2) the sign nature of the information - a text, music, cartographic publications (maps and schematic maps), atlases and albums; 3) the frequency and structure - books, brochures, collections, series and serials; 4) the purpose and character of information educational publications (textbooks, manuals, practical work, training methodical manuals). Thus, a textbook is a type of educational book, which has a clearly defined purpose, submitted by a set of functions.

It is found that the textbook as an information and methodical tool of higher vocational education's management is a printed or electronic publication, outlining the basis of scientific knowledge on a particular subject, in accordance with state standards of higher vocational education, the objectives of educational curriculum, the requirements of didactics, and including tools to manage the process of this knowledge's cognition. Under the textbook's functions can be understood it's purposefully formed properties as a carrier of content and basic information and methodical tool to manage higher vocational education. It is found that the textbook fulfills the following functions: 1) information one, which reflects the inclusion in the content of the textbook of the required array of scientific knowledge; 2) the transformational one, providing transformation of 
scientific data into a form that is accessible and understandable for students; 3) systematizing one, aimed to structure the knowledge in the system that provides a comprehensive perception; 4) organizational and procedural one, which provides management of education process; 5) the function of fixing and selfcontrol, aimed at assimilation of knowledge; 6) the function of self-education, which allows to use the textbook as an autonomous learning tool; 7) research and scientific one, providing as high theoretical level of knowledge expounded, so the formation of students' abilities and skills of research activities; 8) integrating one, showing the place of the studied subject in the sciences' system; 9) coordinating, defining the place of the textbook in the didactic system of tools, forms and methods of training; 10) social one, contributing to the formation of students' philosophical foundations, as in everyday life so in professional activities.

Types of books as information and teaching resources to manage higher vocational education are identified: 1) classic one, corresponding to the established traditions of vocational education and possessing an encyclopedic or monographic nature; 2) divergent one, focused on professional and personal development of students, the formation of a creative personality, and including invariant (providing a minimum set of knowledge required for all students) and variable (providing an additional set of knowledge, expanding opportunities for professional and personal development of future professionals) components; 3) copyright one, designed for specific audiences, taking into account a certain number of lecture hours, lab and practical training; 4) electronic one, including a set of information, methodical and software tools to complement the prints intended for the study of a particular subject and containing the questions and tasks for self-checking and verification of knowledge (Akhmetov et al., 2016 ).

\section{Modern requirements for the content and structure of the textbook}

Content is a philosophical category which represents the unity of all the constituent elements of the object, its properties, internal processes, relations, contradictions, trends (Ilyichov et al., 1983). It is found that the content of the textbook is regarded as a system of knowledge, subject and educational skills, creativity, emotionally-valuable attitude to the subject of study, according to the level of development of science, technology and culture.

In the text of the textbook it is the amount, but the system of basic and subject knowledge is reflected, stimulating thinking of students, contributing to focusing on the problem and perspective issues of development of specific science and civil society (Yepaneshnikov et al., 2016; Zakirova et al., 2015). Knowledge is a key component in the content of training; objective information about these or other objects of reality, consciously perceived and recorded in the memory, assimilated till the level of awareness of internal and external relations, availability of creative use. The characteristics of quality of knowledge can be: consistency; continuity; generalization; responsiveness; flexibility; being integrative. Currently increasing flow of information leads to greater importance of compact layout of knowledge in the textbook. Therefore, the mandatory components of the educational material - is a set of terms and concepts, facts, activities' kinds.

Each textbook should provide formation of students' subject skills (math, geography) and educational abilities, aimed at the organization of the 
educational process (fast reading, writing, notes, compiling of a bibliography, and so on). Educational abilities are distinguished on: 1) organizational (making of actions' plan, etc.), 2) practical (references' using, work with graphs, etc.), 3) intelligent (the formulation of ideas, finding solutions to problems, and so on. n.) abilities. If the knowledge is assimilated by the conscious perception of the text, the abilities are fixed and formed by exercises.

Therefore, when creating of a textbook one should collect the abilities' system, to decompose the ability on operations, spread them according to topics, combine tasks on mastering of all the abilities with the fundamental and subject knowledge.

Creative work's experience is acquired by problem tasks' solving in different their forms. In the text-book, this component is fixed by problematic presentation of the text and by the problem, research objectives, linked to a certain system of indicators. Reflection in the textbook's content of knowledge's system, subject and educational skills, creative activities provides that each successive component is built on the previous ones. It involves three levels of knowledge's assimilation, subject and educational skills, creative activities: 1) the conscious perception and memory, expressed in their direct reproduction; 2) their application according the sample under similar conditions; 3) creative use in unfamiliar situations. These three levels determine the nature of the tasks. The set of tasks doesn't take into account only levels' mastering, but also the situation of using of each knowledge, ability and ways of creative activities dictated by the nature of the subject. These situations are highlighted by the author of the textbook in accordance with the curriculum and presentation's logic. Creative activities' experience contributes to the formation of students' interest in knowledge and in the process of its acquisition, realization of practical and theoretical significance of the studied knowledge, the creation of situations of success in academic work (Petrova et al., 2016).

The experience of emotionally-valuable attitude to the subject matter is reflected in the textbook by including of special assignments for objects' evaluation, identifying of their importance for themselves, the ratio of the studied and already developed personal system of values. Not all of the information in the textbook is able to have an impact on the emotional sphere of students. But every subject contains aspects which are able to update the emotions: the process of creative activities, aesthetic design, the promotion of self-affirmation and self-manifestation, reflection, clarity, elegance of evidence and brightness of presentation, presenting of moral and philosophical problems. Experience of emotional and valuable attitude is acquired through experience, and all these aspects of the content are aimed to provide experience. For the successful acquisition of knowledge it is necessary to provide motivation for teaching, that is, to form the inner motivation, stimulating the student to active creative work. These motifs can be an experience of emotional and valuable attitude.

It is found that the structure of the textbook is a reflection of its content and functions. There are three main components can be identified in the structure of the textbook. The first component is composition (text part and illustrations). The composition consists of three parts: introduction, main one and conclusion. Introduction is a preamble (foreword). The final part is a conclusion (afterword). The main part consists of sections, chapters, paragraphs. Famous Russian textbooks' writer N. I. Tupalsky (1976) identifies major part as the 
architectonics of the textbook. He believes that the sections of the textbook should correspond with the educational process: the sections correspond with semester, chapter of the lesson - training's cycle; paragraph - one lesson. The textbook on the subject, designed for two semesters, according to N. I. Tupalsky (1976), should consist of two sections, for three - of three, for four - of four. The textbook for a one semester - discipline should not contain sections at all. In our opinion, this practice is poorly applied to the textbook for university students, which, on the one hand, is connected with lecture and seminar system, on the other - more focused on student's independent work. In addition, currently a student (and teacher) cannot deal with a single textbook on the subject. It is believed that the main part of the textbook should be determined by scientific logic. The basic structural and semantic unit of the textbook is the chapter, which is accompanied by educational tasks.

The term "training task" is given a lineal value, considering the notions "exercise" and "problem" as specific one. This terminology is the most logical one, since the word "task" can define any structure, causing one or another kind of student's activities. Namely, it is a function of all the questions, exercises and tasks, which are introduced in the textbook's chapters, direct activities' mastering and the ways of information processing, - promotion and organization of students' various activities required for mastering of the content of educational subjects. Targets have a definite structure: 1) the impulse to activities (question, requirement and instruction.); 2) the activities carried out on a particular content. Outwardly, this structure is not always detected. Only the impulse can be expressed - the instruction to the task, and the content on the basis of which the activities is deployed, can be given earlier (for example, in the form of educational text), it can be assumed to be known from the experience of the students. In many tasks, however, the prescription and the material are given (in the form of specific sentences or the text, visual material). Training tools in the tasks, thus, are writing and presentation. Tasks are varied by types depending on the kind of activities they are aimed to develop - reproductive or creative. If the task includes an action's fulfillment on the model and on the basis of known rules (formulas) and it requires students' fulfillment of the previously performed activities, it is "exercise". If the student based on the number of data searches for the material and methods of activities, the sample, which was not in his previous experience, such a task is a "challenge". The classification of tasks to one or another kind is independent from the form of instruction. Question may cause reproductive and creative activities, depending on how its content correlates with the degree of assimilation of educational material, how it correlates with the content of the text which was previously assimilated. If the question involves finding of a direct answer in the text or it (the answer) is known from experience, the task is to be considered an "exercise". If there is no direct answer in experience, training texts students need independent search, converting of the previously assimilated material, the task should be classified as a "task." A situation can happen, when it is assumed one thing, but in the actual process of learning another thing is obtained. For example, students are not prepared well to carry out the exercises, and it turns into a problem for them.

The second component of the textbook's structure is the apparatus organization of assimilation (questions-assignments, examples, tasks, summarizing tables, conclusions). The apparatus organization of assimilation is 
necessary for independent work of a student, for self-control of the acquired knowledge and it contributes to the development of skills to operate with concepts, tools and techniques of specific discipline. The composition of the apparatus organization of assimilation is quite diverse and includes instructional and teaching materials, tables for assimilation's organization, questions and tasks for different purposes and types, exercises for training and independent works' organization, highlighting in the text, etc.

The third component of the structure of the textbook is reference and accompanying apparatus (abstract, imprints, pointers, table of contents (content). Reference and accompanying textbook's apparatus performs additional functions in relation to the composition. It provides information about the book and contains the apparatus of publication and apparatus of orientation. Publication's apparatus includes such elements as abstract, which gives very brief information about the book, its author, the problems; imprints. Orientation's apparatus includes pointers, the table of contents (content) (see. Table 1).

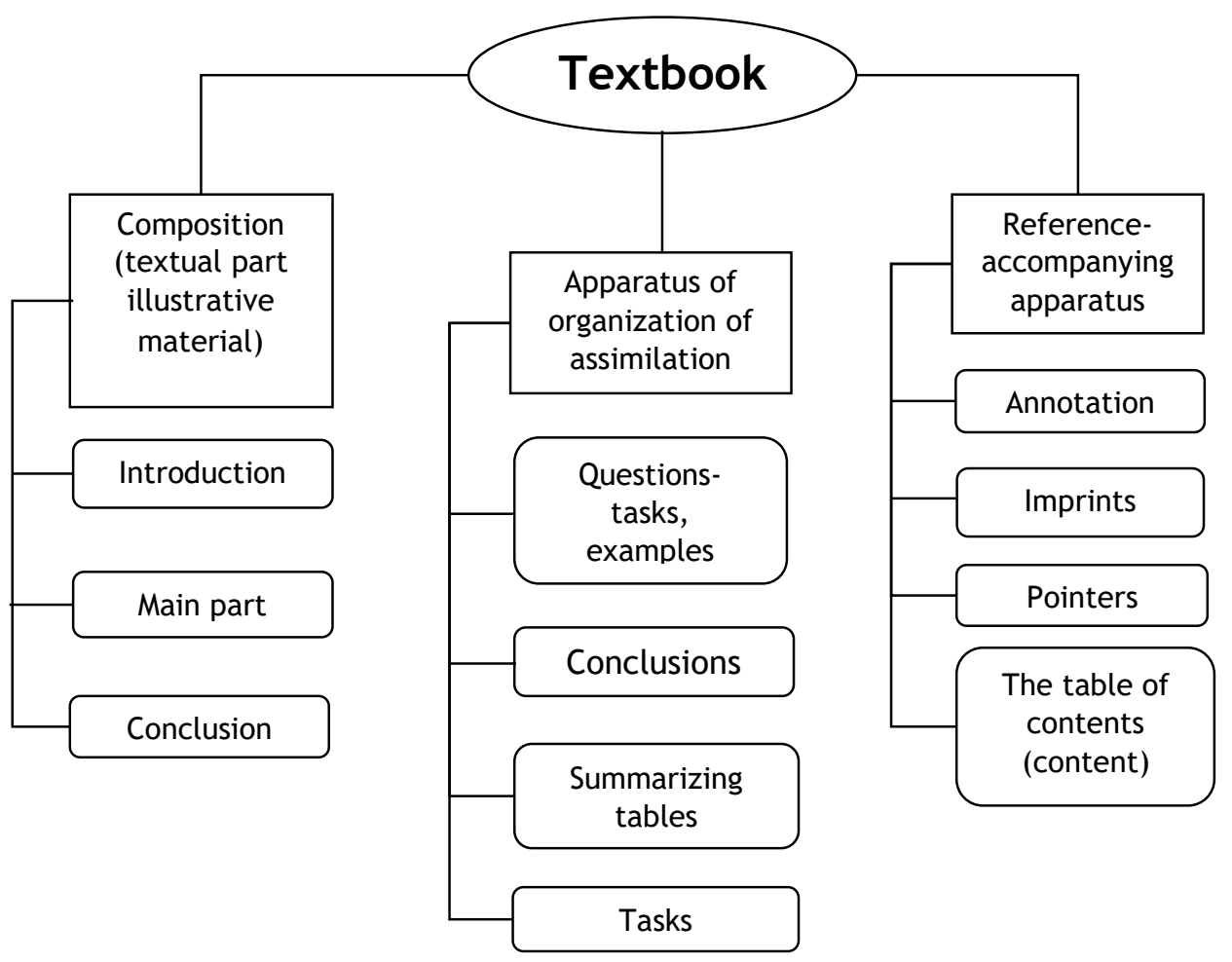

Figure 1. The structure of the textbook

From figure 1 it is evident, that the structure of a university textbook of new generation is to contain, firstly, composition (text department and illustrative material), where the introductory (introduction and foreword), basic and final (conclusion, afterword) parts are allocated; secondly, apparatus of organization of assimilation (questions-tasks, examples, tasks, summarizing 
tables, conclusions) is allocated; thirdly, a reference-accompanying apparatus (annotation, imprints, pointers, table of contents) is allocated.

\section{Experimental verification of modern requirements' efficiency to the content and structure of the textbook}

Experimental verification was conducted from 2014 till 2016. 300 teachers and 300 students took part in experimental verification. Experimental verification was conducted in three stages: ascertaining, forming and control one.

Within the framework of the ascertaining stage the requirements of teachers and students to the structure and content of the textbooks were studied. It is established that students as the basic requirements put forward: availability of exposition of knowledge; clear denotation of themes; presence of necessary reference apparatus. Questioning of students shows that they prefer to use textbooks having a sign marked by the Department of education and science of Russian Federation, or textbooks, published by university publishing houses, made by the teachers of university, and containing material necessary for the successful test or examination's passing. Teachers prefer the textbooks in which the content corresponds to basic directions of development of scientific idea and requirements of state educational standards, the structure includes the logical and rational method of exposition of knowledge, aimed to form the ability to think. It is found out that teachers prefer textbooks having sign marked by Department of education and science of Russian Federation. On this stage two levels of preparation and edition of textbooks are revealed: 1) federal, on which the textbooks are published by the publishing houses specialized on producing of educational literature, and have a sign marked by the Department of education and science of Russian Federation; 2) local, on which the textbooks are published by university publishing houses, and are an algorithm of study of certain discipline.

On the forming stage taking into account modern requirements to the textbook's content and structure the project of textbook on history (see table 1) was developed.

Planning of the textbook included three stages. 1. Theoretical justification: forming of informational base of educational-scientific knowledge; determination of aims and tasks of the content; construction of conceptual charts, justification of intercommunication of components of the content; development of criteria for selection of the content of the educational material. 2 . Structural and semantic selection of the content: certain systems of theoretical knowledge, providing fundamentality of education, and practical knowledge making basis of educational abilities and skills; establishing of interdisciplinary connections; a selection in the content of historical knowledge of basic components : a) of invariant part, being integrity of concepts, social laws, facts and other; b) of the specialized part including image exposition of material; c) of world view part providing the world view orientation of educational knowledge. 3. Methodical support of the selection and structuring of the content of educational material: making of technological card (goal-setting, dosage of tasks for independent work of students, forms and methods of teaching, methods of diagnostics and correction work); taking into account of the individual age-related features of students; forms and methods of work with the gifted students. 
Table 1. Project of the textbook on history

\begin{tabular}{|c|c|c|}
\hline \multirow[t]{8}{*}{ Actual material } & \multirow{3}{*}{$\begin{array}{l}\text { Terms (terminological } \\
\text { apparatus) } \\
\text { Concepts (conceptual } \\
\text { apparatus) }\end{array}$} & $\begin{array}{l}\text { Commonly used terms } \\
\text { Terms, requiring explanation }\end{array}$ \\
\hline & & Basic concepts \\
\hline & & Additional concepts \\
\hline & \multirow{3}{*}{$\begin{array}{l}\text { Dates (chronologic } \\
\text { apparatus) }\end{array}$} & Main dates \\
\hline & & Dates designating scopes of the stages \\
\hline & & Additional dates \\
\hline & \multirow{2}{*}{$\begin{array}{l}\text { Proper (personalities) } \\
\text { names }\end{array}$} & Main personalities \\
\hline & & Additional personalities \\
\hline \multirow[t]{3}{*}{ Theoretical material } & \multicolumn{2}{|c|}{ Description of basic regularities } \\
\hline & \multicolumn{2}{|c|}{ Reflection of basic theories } \\
\hline & \multicolumn{2}{|c|}{ Descriptions of leading ideas and perspective directions. } \\
\hline \multirow{3}{*}{$\begin{array}{l}\text { Methodological } \\
\text { material }\end{array}$} & \multicolumn{2}{|c|}{ Methodological approaches } \\
\hline & \multicolumn{2}{|c|}{ Principles } \\
\hline & \multicolumn{2}{|c|}{ Methods of scientific researches } \\
\hline \multirow[t]{3}{*}{ Educational material } & \multicolumn{2}{|c|}{$\begin{array}{l}\text { Materials forming the emotionally-valued attitude toward the world } \\
\text { (including personality descriptions of historical, political figures). }\end{array}$} \\
\hline & \multicolumn{2}{|c|}{ World view and ideological generalizations and estimations. } \\
\hline & \multicolumn{2}{|c|}{ Description of ideological, moral and aesthetic norms } \\
\hline \multirow[t]{3}{*}{ Didactic material. } & \multicolumn{2}{|c|}{$\begin{array}{l}\text { Receptive (directed on the material's assimilation) (instructional- } \\
\text { methodical materials of different kind, tables for content's } \\
\text { assimilation, color, type and structural excretions of text, } \\
\text { signatures to illustrative materials) }\end{array}$} \\
\hline & \multicolumn{2}{|c|}{$\begin{array}{l}\text { Reproductive (directed on the reproducing of the perceived) } \\
\text { (exercises, questions-tasks of reproductive character within the } \\
\text { framework of textbook) }\end{array}$} \\
\hline & \multicolumn{2}{|c|}{$\begin{array}{l}\text { Productive (creative) (questions-tasks for independent work out of } \\
\text { scopes of the textbook, themes of test, course works, reports) }\end{array}$} \\
\hline \multirow[t]{4}{*}{ Reference material } & \multicolumn{2}{|c|}{$\begin{array}{l}\text { Materials for an orientation in subject content of the textbook } \\
\text { (subject, chronologic, pointers, pointer of the names, pointer- } \\
\text { dictionary of foreign words, orienting foreword, orienting } \\
\text { afterword) }\end{array}$} \\
\hline & \multicolumn{2}{|c|}{$\begin{array}{l}\text { Materials for an orientation in the structure of the textbook (table } \\
\text { of contents). }\end{array}$} \\
\hline & \multicolumn{2}{|c|}{$\begin{array}{l}\text { Materials characterizing educational edition (annotation, imprints, } \\
\text { different kind of pointers, sign of copyright). }\end{array}$} \\
\hline & \multicolumn{2}{|c|}{$\begin{array}{l}\text { Reference (additional) sources (bibliographic pointer and } \\
\text { supplements). }\end{array}$} \\
\hline
\end{tabular}

On the control stage the criteria of quality's estimation of the textbook were defined and the estimation of project's quality of the textbook on history was performed (table 2). 
Table 2. Results of teachers' and students' questioning about the quality of the textbook's project on history (in percent)

\begin{tabular}{lcc}
\hline Estimation criteria of the textbook's quality & Teachers & Students \\
\hline $\begin{array}{l}\text { The relevance of the content (accordance to the level of } \\
\text { development of science, technique, culture and state educational } \\
\text { standards) }\end{array}$ & 95 & 89 \\
$\begin{array}{l}\text { Availability of the content (taking into account of the age-related } \\
\text { features of students; regularities of perception of written texts). }\end{array}$ & 94 & 83 \\
$\begin{array}{l}\text { Optimality of structure (unity of the content and apparatus of } \\
\text { organization of knowledge's assimilation; systematic character } \\
\text { and system of exposition of educational material) }\end{array}$ & 98 \\
$\begin{array}{l}\text { Multi-functionality of structure (accordance to the requirements } \\
\text { of personality's development, science's development, state } \\
\text { educational standards). }\end{array}$ & 86 & 78 \\
$\begin{array}{l}\text { Reliability (providing of identically stable high results of students' } \\
\text { education with different level of intellect). }\end{array}$ & 88 & 91 \\
\hline
\end{tabular}

From the table 3 it is evident, that students and teachers gave positive estimation of the textbook's project on history.

\section{Discussions}

Problems of the textbook as informatively-methodical tool to manage education are the subject of many researches. All these researches can be conditionally divided into two groups. The first group unites researches of authors, who consider the textbook as a book, expounding bases of scientific knowledge on a certain educational subject. Russian scientist V. G. Beilinson (1986) marks that a textbook: incarnates the content of educational discipline and gives a minimum of necessary facilities for its complete assimilation (understanding, memorizing, application); drives students in the integral world of culture, providing its assimilation, converting into the property of personality; forms and asserts the self-founding of civilization - system of values of our society. From the point of view of D. D. Zuyev (1983), a textbook is a mass educational book, expounding the subject content of education and determining the types of activities, intended by the curriculum for the obligatory assimilation by students taking into account their age-related or another features. In opinion of N. I. Tupalsky (1976), a textbook is a genre of educational literature, the subject content of which are the bases of certain discipline, expounded in accordance with the set curriculum). In research of A. K. Kusainov \& U. A. Asylov (2003) a textbook is determined as a book, expounding bases of scientific knowledge on a certain educational subject in accordance with the aims of teaching, defined in the curriculum, and requirements of didactics.

The second group unites researches of authors, who consider that a textbook does not only expounds bases of scientific knowledge on a certain educational subject but also reflects its teaching methodology. L. M. Kitsina \& I. S. Skovorodina (2004) consider that development of a textbook is the work on educational process's planning. Textbooks can be used actually on all stages of the teaching process, here they can undertake the functions of teacher fully or partly. From the point of view of T. S. Nazarova \& J. P. Gospodarik (2005) a textbook is called to serve to the organization of the whole process of teaching. In opinion of V. K. Batsyn \& K. L. Butyagina (2005) in the textbook not only the students' activities but also the teacher's supposed activities are objectified and programmed. P. G. Buga (1987) offers the following formulation of the textbook's 
definition: it is educational edition containing systematic exposition of the model curriculum of educational discipline or its theoretical part, at high scientificallymethodical level and officially ratified as a textbook.

It is considered, that to determine the functions of modern textbook it is necessary to take into account all the opinions, but it is important to remember that for the different stages of education the textbooks are not of equal value. They are differentiated by the volume of the given information, by the language of exposition, consideration of different points of view on problems, the textbook for higher vocational education possesses research function, that doesn't contribute to the simple memorizing of actual material, but to the establishment of dependences, revealing and research of problems. Therefore offering understanding of the textbook's essence, we paid attention as to scientific knowledge so to the instruments of working with them. The table of contents of textbook specifies educational aims, structure- the tools of management by the process of knowledge's study.

\section{Conclusion and Recommendations}

It is found out that giving to the universities a large number of rights on the determination of the content, choice of forms and methods of education causes the introduction of the authorial curricula, supported by the creation of original textbooks, reflecting the variety of approaches to the exposition of scientific knowledge. Textbook as informatively-methodical tool to manage the high vocational education provides intercommunication of science and corresponding educational discipline. The basic functions of the textbook are aimed to system transferring of necessary array of scientific knowledge in the form which is accessible and clear to the students; creation of mechanism to assimilate and fix educational material, forming the students' abilities and skills of research activities and world view bases.

In the textbook's content as informatively-methodical tool to manage high vocational education it is possible to distinguish four components (knowledge, subject and educational abilities, creative activities, emotionally-valuable attitude to the object of study), which are different by functions and assimilation's method. The table of contents of every textbook has these four components, but in a different proportion. There is more knowledge in one textbook and there is more abilities in others. A table of contents of the textbook is not a totality of knowledge, subject and educational abilities, creative activities, emotionally-valuable attitude to the object of study, but their system integrity, aimed to transformation of social experience in the personal and providing the efficiency of students' self-realization, success of their socialization. While determination of requirements to the university's textbook it is necessary to come from the pedagogical tasks solved with its help. Thus for the successful assimilation of educational material it is necessary to provide motivation of studies, to form an internal motive, a stimulant for student's active creative work. Therefore there must be educational material in a textbook, a stimulant for the student's thinking, assisting the attention's focusing on the problem and perspective questions of development of certain science. It is important, to include in the textbook questions, illustrations, charts, tables, diagrams that create a problem situation and cause students' need in assimilation of necessary knowledge. 
Structure of the textbook : 1) corresponds to logic of the studied scientific discipline; 2) presents dialectical intercommunication of text and illustrative material; apparatus of organization of fundamental and subject knowledge's assimilation, subject and educational ability, experience of creative activities and emotionally-valuable attitude to the object of study; referenceaccompanying apparatus; 3) aimed to development of the innovative thinking, independence and creative activities of students.

The conducted study allows making of the following conclusions. Firstly, the efficiency of the textbook's content is increased in case of integration of fundamental, subject and professional knowledge. Secondly, the improving of the textbook's structure is achieved in condition of system alternation of text, illustrative material, apparatus of organization of knowledge' assimilation (questions-tasks, examples, tasks, summarizing tables, conclusions). Thirdly, the value of estimation's criteria of textbook's quality is increased in condition of taking into account of actuality and availability of the content, optimality and multi-functionality of the structure, reliability of the textbook (providing of identically stable high results of students' education with the different level of intellect).

The research results allow defining of the prospects for further researches of this problem, which are connected with the use of the textbook as informativelymethodical tools to increase students' cognitive motivation, to organize and manage their cognitive activities; with the technology of preparation and application of electronic textbooks.

\section{Disclosure statement}

No potential conflict of interest was reported by the authors.

\section{Notes on contributors}

Ibragim D. Ibragimov is $\mathrm{PhD}$, Associate Professor of Pyatigorsk State Linguistic University, Pyatigorsk, Russia;

Svetlana V. Dusenko is PhD, Associate Professor of Russian State University of Physical Education, Sport, Youth and Tourism, Moscow, Russia;

Elmira R. Khairullina is $\mathrm{PhD}$, Professor of Kazan National Research Technological University, Kazan, Russia;

Natalia V. Tikhonova is $\mathrm{PhD}$, Associate Professor of Kazan National Research Technological University, Kazan, Russia;

Olga G. Yevgrafova is PhD, Associate Professor of Kazan (Volga region) Federal University, Kazan, Russia.

\section{References}

Akhmetov, L. G., Khramova, N. A., Sychenkova, A. V., Chudnovskiy, A. D., Pugacheva, N. B., Pavlushin, A. A., Varlamova, M. V., Khilsher, V. A. (2016). Selective Support for the Development of Regional Vocational Education Services: the Russian Experience. International Review of Management and Marketing, 6(2S), 127-134.

Baklashova, T. (2014), Managers' Professional Training in Russia: Syllabus and Technologies. Procedia - Social and Behavioral Sciences, 152, 1057-1061.

Baklashova, T. A., Galishnikova, E. M., Khafizova, L. V. (2015) The Effects of Education on Tolerance: Research of Students' Social and Ethnic Attitudes. Mediterranean Journal of Social Sciences, 6(1 S3), 335-340.

Batsyn, V. K. \& Butyagina, K. L. (2005) Development of market of educational literature in Russian Federation: role of the Innovative project of development of education. Moscow: Logos. 196p. 
Beilinson, V. G. (1986) Arsenal of education: description, preparation, constructing of educational editions. Moscow: Book. 286p.

Bespalko, V. P. (1986) Theory of textbook: the Didactic aspect Moscow: Pedagogics. 160p.

Buga, P. G. (1987) University textbook: Creation, producing, distribution. Moscow: Publishing Book. $158 \mathrm{p}$.

Ilyichov L. F., Fedoseyev P. N., Kovalyov S. M., Panov V. G. (1983) Philosophical encyclopaedic dictionary. Moscow: Soviet Encyclopedia. 840p.

Kalimullin, A. M. \& Vasyagina, N. N. (2015) Retrospective analysis of social and cultural meanings of motherhood in Russia. Review of European Studies, 7(5), 61-65.

Kamalova, L. A. \& Zakirova, V. G. (2015) The formation of the pedagogical values of future primary school teachers at the University. Review of European Studies, 7 (5), 1-9.

Kamasheva, Y. L., Goloshumova, G. S., Goloshumov, A. Y., Kashina, S. G., Pugacheva, N. B., Bolshakova, Z. M., Tulkibaeva, N. N., Timirov, F. F. (2016) Features of vocational education management in the region. International Review of Management and Marketing, 6(1), 155-159.

Kitsina, L. M. \& Skovorodina I. S. (2004) Preparation of educational editions in institution of higher education: reference manual for authors. Omsk: Omsk State University. 127p.

Kusainov, A. K. \& Asylov, U. A. (2003) Actual problems of textbook writing Moscow: Inlightening. $86 \mathrm{p}$.

Lisitzina, T. B., Kovaleva, N. I., Shaikhlislamov, A. K., Minsabirova, V. N., Shaidullina, A. R., Pavlova, N. A., Nevenchannaya, Y. V. (2015) Practical recommendations for the teachers on optimization process of the students majoring in Tourism. Asian Social Science, 11(1), 154-158.

Masalimova, A. R., Zakirova, V. G., Chernova, Y. A., Drovnikov, A. S., Shaidullina, A. R. \& Sakhieva, R.G. (2014) Structure and content of mentors psychological and pedagogical training curriculum. Life Science Journal, 11(7s), 381-386.

Nazarova, T.S. \& Gospodarik, J.P. (2005) Strategy of development of educational book. Pedagogics, $3,11-19$.

Petrova, T. N., Kirillova, O. V., Sokolova, S. G., Pugacheva, N. B., Galimullina, A. F., Maksimova, O. G., Antonova, T. V., Kozhanov, V. V. (2016) Education as the Management of Research Universities Students' Socialization. International Review of Management and Marketing, $6(2 S)$, 28-33.

Pugacheva, N. B., Kirillova, T. V., Ovchinnikova, I. G., Kudyashev, N. K., Lunev, A. N., Pavlova, O. A., Kashina, S. G., Valeyev, A. S. (2016) The Mechanism of State-Public Management of Vocational Education in the Region. International Review of Management and Marketing, $6(2 S), 6-11$.

Sakhieva, R. G., Khairullina, E. R., Khisamiyeva, L. G., Valeyeva, N. Sh., Masalimova, A. R. \& Zakirova, V. G. (2015a) Designing a Structure of the Modular Competence-Based Curriculum and Technologies for Its Implementation into Higher Vocational Institutions. Asian Social Science, 11(2), 246-251.

Sakhieva, R. G., Majkova, L. V., Emelyanova, M. V., Gavrilova, N. G., Sharonova, E. G., Gatina, A. R., Pavlova, N. A. \& Baklashova, T. A. (2015b) The Supplementary Education Teacher's Portfolio: Essence, Functions, Structure and Design Principles. Mediterranean Journal of Social Sciences, 6 (2 S3), 84-89.

Sakhieva, R. G., Semenova, L. V., Muskhanova, I. V., Yakhyaeva, A. Kh., Iskhakova, R. R., Makarova, E. V. \& Shafigullina, L. Sh. (2015c) Academic mobility of high school students: concept, principles, structural components and stages of implementation. Journal of Sustainable Development, 8 (3), 256-262.

Shaidullina, A. R., Merzon, E. E., Zakirova, V. G., Mokeyeva, E. V., Karev, B. A., Burdukovskaya, E. A., Polevaya, N. M. (2015a) The Peculiarities of Perspective Students Selection Mechanism by the Future Employers-Enterprise. Review of European Studies, 7(1), 68-73.

Shaidullina, A. R., Pavlova, N. A., Minsabirova, V. N., Burdukovskaya, E. A., Yunusova, A. B., Letyaev, V. A., Afanasev, A. S. (2015b) Integration Processes in Education: Classification of Integration Types. Review of European Studies, 7(4), 27-31.

Telegina, N. V., Galimova, E. G. \& Masalimova, A. R. (2015) The Structure and Content of the Model of Pedagogical Conditions Binary Approach to Optimization of Control and Diagnostic Functions in Teaching "General pedagogy" to Students. Asian Social Science, 11(1), 364-368.

Vlasova, V. K., Kirilova, G. I. \& Sabirova, E. G. (2015) Functioning of information educational environment: Meta dynamic approach. Review of European Studies, 7 (5), 25-30.

Vlasova, V. K., Kirilova, G. I., Curteva O. V. (2016) Matrix classification of information environment algorithms application in the educational process. Mathematics Education, 11(1), 165-171.

Yashkova, A. N. \& Kalimullin, A. M. (2015) The features of manifestation of students' subjectness. Review of European Studies, 7(5), 211-216.

Yepaneshnikov, V. V., Pugacheva, N. B., Goloshumova, G. S., Kuznetsova, V. V., Dobrovolskaya, L. V., Moiseeva, L. V., Garaganov, A. V., Litvinenko, N. A. (2016) Pedagogical Management of 
$446 \odot \odot \quad$ I.D. IBRAGIMOV ET AL.

Civil Education of Research Universities Students. International Review of Management and Marketing, 6(2S), 23-27.

Zakirova V. G. \& Koletvinova N. D. (2014) Paradigm of future primary school teachers' vocational training. Life Science Journal, 11(4), 441-447.

Zakirova V. G., Gaysina, G. I. \& Zhumabaeva, A. (2015) Program of adaptation assistance in foster families and particular features of its implementation. International Journal of Environmental and Science Education, 10(4), 553-559.

Zuyev, D. D. (1983) School textbook. Moscow: Pedagogics. 238p. 